\title{
Sistem Informasi Penjualan Berbasis Web Toko Satunusa Ritel Tanjungpinang
}

\author{
Sabda Alamsyah ${ }^{1}$, iim Eldapendra ${ }^{2}$, Liza Safitri ${ }^{3}$ \\ 1,3 Jurusan KomputerAkuntansi STT Indonesia Tanjungpinang \\ Jln. Pompa Air No. 28 Tanjungpinang Kepulauan Riau Indonesia \\ ${ }^{1}$ sabdaalamsyah93@gmail.com \\ 2iim@sttindonesia.ac.id \\ ${ }^{3}$ lizasafitri@sttindonesia.ac.id
}

\begin{abstract}
Intisari - Toko Satunusa merupakan perusahaan yang bergerak dalam bidang penjualan bahan jahit. Toko Satunusa melakukan proses pendataan dan perhitungan stok barang yang berjalan secara manual. Dimana proses manual ini menimbulkan permasalahan. Kelemahan dari proses sistem penjualan ini adalah kurang efisien dan efektif dan memakan banyak waktu dalam pembuatan laporan. Perangkat lunak yang digunakan sebagai alat bantu dalam penelitian serta perancangan sistem baru yaitu Dreamweaver cs3 dengan menggunakan metedologi waterfall untuk mengaplikasi perkembangannya. Hasil pengembangan dari sistem Dreamweaver cs3 dapat memberikan potensi kerja yang cepat dan akurat serta efisiensi sehingga dapa menigkatkan potensi toko. Aplikasi Sistem Informasi Penjualan yang dihasilkan mampu mengelola data penjualan, yang meliputi data transaksi pembelian barang, data transaksi penjualan barang, data barang, data supplier dan data stok secara terorganisasi, serta menghasilkan laporan yang lengkap, akurat dan aktual. Sistem Informasi Penjualan menggunakan sistem website.

Kata kunci-Sistem Informasi, Penjualan Peralatan Komputer, Website.,
\end{abstract}

Abstract - Satunusa Store is a company engaged in the sale of computer equitment. Saunusa Shop two performs the data collection process and calculates the inventory that runs manually. Where this manual process raises problems. The weakness of this sales system process is that it is less efficient and effective and takes a lot of time in making reports. The software used as a tool in the research and design of new systems is dereamweaver cs 3 using the waterfall methodology to apply its development. The results of the development of the system are expected to provide the potential for fast and accurate work and efficiency so that it can increase the store's potential.The resulting Sales Information System application is able to manage sales data, which includes goods purchase transaction data, goods sales transaction data, goods data, supplier data and stock data in an organized manner, and produce complete, accurate and actual reports. Sales Information System uses the website system

Keywords: Information System, Sales of computer equitment, website.

\section{Pendahuluan}

A. Latar Belakang

Sistem informasi merupakan satu faktor penting dalam suatu intansi maupun perusahaan karena memiliki rutinitas yang tinggi dan pengolahan data yang termanajemen. Sistem informasi digunakan untuk mengumpulkan, mengolah dan menyediakan informasi. Data dan informasi yang diperoleh suatu instansi atau perusahaan terus-menerus bertambah banyak sehingga tidak mudah untuk diolah dengan cara manual. Oleh karena itu di perlukan sistem informasi berbasis komputer bagi setiap instansi atau perusahaan agar dapat memudahkan proses manajemen data dengan baik.

Toko Satunusa adalah toko yang bergerak di bidang penjualan dan servis komputer. Kegiatan operasional pada Toko Satunusa khususnya untuk peralatan komputer ini belum mempunyai sistem yang baik. Seperti hanya mencatat stock yang masih manual atau masih menggunakan tulis tangan

pada kartu stock barang, sehingga untuk mendapatkan data yang dibutuhkan harus di cari satu persatu karena di simpan sesuai urutan tanggal pemasukan dan pengeluaran barang setiap harinya.

Salah satu informasi yang di butuhkan pada toko satunusa adalah mengelai persediaan pengolahan data barang masuk, barang keluar, dan persediaan yang ada di gudang atau stok barang. Permasalahan yang ada saat ini adalah kurangnya teliti pada laporan yang di buat sehingga terkadang terjadi kesalahan. Hal tersebut dapat di hindarkan dengan menggunakan suatu sistem agar dapat secara cepat, tepat, untuk penjualan, sehingga dapat memudahkan dalam penjuala, pengumpulan, pengolahan, dan Penyimpanan data. Melihat akan pentingnya persediaan barang pada gudang toko satunusa, maka dalam penyusunan ini penulis bermaksud untuk meninjau permasalahan dan sudut ilmu yang penulis peroleh dari perkuliahan di STTIndonesia Tanjungpinang Kepulauan Riau untuk mengadakan penelitian mengenai 
persediaan barang dengan judul sebagai berikut "Sistem Informasi Penjualan Berbasis Web Pada Toko Satunusa Ritel Tanjungpinang".

\section{B. Identifikasi Masalah}

Identifikasi masalah adalah pengelompokkan masalah penelitian yang dilakukan atau masalah yang akan dijadikan objek penelitian. Masalah penelitian akan menentukan kualitas dari penelitian, bahkan juga menentukan apakah sebuah kegiatan bisa disebut penelitian atau tidak. Adapun identifikasi masalah yang ada pada Toko Satunusa adalah sebagai berikut:

1. Pada Toko Satunusa pencatatan persediaan barang masih menggunakan buku.

2. Besarnya resiko kehilangan data penjualan yang di sebabkan pencatatan penjualan yang masih bersifat manual, yaitu di pencatatan ke dalam buku.

3. Pengolahan data penjualan belum menggunakan metode sehingga penjualan masih tidak teratur.

\section{Tujuan Penelitian}

Adapun dilaksanakannya penelitian pada Toko Satunusa ini bertujuan untuk sebagai berikut :

1. Mampu menyajikan informasi penjualan yang cepat dan akurat.

2. Mampu menampilkan persediaan barang pada gudang Toko Satunusa .

3. Untuk memunimalisir kesalahan perhitungan stock barang.

D. Kajian Pustaka

1. Sistem

Sistem adalah cara-cara yang diorganisasi untuk mengumpulkan, memasukkan, dan mengolah serta menyimpan data, dan cara-cara yang diorganisasi untuk menyimpan, mengelola, mengendalikan, dan melaporkan informasi sedemikian rupa sehingga sebuah organisasi dapat mencapai tujuan yang telah ditetapkan.Krismaji (2015 : 15) [1].

\section{Pengertian Sistem Informasi Berbasis Komputer}

Sistem komputerisasi akuntansi merupakan "aplikasi dari accounting system yang berbasis sistem database dengan menggunakan teknologi komputer". Pengertian menurut Mardi (2014:29) [2] :Dalam sistem akuntansi terkomputerisasi., ada program-program yang digunakan dalam menjalankan siklus akuntansi, seperti penjurnalan, posting (pembukuan) dan penyususunan neraca saldo. Dalam sistem yang erkomputerisasi, jurnal dan buku besar dapat dicatat dalam basis data (database) komputer. Lebih jauh lagi, telah ada software untuk menjalankan sistem bisnis seperti fungsi penagihan, fungsi penyiapan penggajian dan fungsi penganggaran. Berdasarkan pengertian diatas maka dapat disimpulkan bahwa Sistem Informasi adalah sebuah sistem yang memproses dan mengumpulkan data serta transaksi untuk menghasilkan informasi yang bermanfaat bagi pihak-pihak yang memerlukanya.

\section{Retail}

Retailer atau eceran yaitu badan usaha yang mendistribusikan barang/jasa kepada konsumen baik biasanya mereka menjual secara eceran. Retailer mempunyai peranan penting baik dalam pendistribusiannya maupun mempromosikan barang tertentu. Seperti slogan diatas "Retail is detail", karena retail mempunyai pengetahuan danpengalaman lebih dalam menjual kepada konsumen.Retail Menciptakan Nilai Lebih Barangdan JasaBayangkan jika anda ingin membuat secangkir kopi untuk menemani anda setiap pagi. Tentu anda perlu membeli beberapa bahan seperti kopi, gula dan krimer. Coba anda bayangkan jika anda harus pergi kesetiap toko(produsen) untuk membeli ketiganya itu. Ditambah bayangkan berapa banyak toko yang akan dibangun untuk membangun satu jenis produk saja. Retail menyediakan 20.000 samapai 30.000 jenis barang dari 500 produsen dari berbagai jenis, ukuran, merk dan harga dalam satu toko. Menurut Dale M. Lewison (1982 : 4) [3], Retail menjual secara enceran biasanya produsen/distributor mengirim barang dalam jumlah besar untuk menekan biaya transportasi. Hal ini tentu akan menyulitkan konsumen, karena mereka hanya membutuhkan sedikit untuk kebutuhan sehari-hari. Retail membantu mereka untuk membeli dari produsen/distributor dan menjual kembali dalam jumlah yang lebih kecil. Mereka juga menyimpan barang tersebut sehingga jika konsumen kala membutuhkan tinggal membelinya melalui retail.Menyediakan Pelayanan (CustomerService), Retail mempekerjakan orang agar dapat memberikan informasi seputar produk tertentu.

\section{Debugging}

Debugging adalah sebuah metode yang dilakukan oleh para pemrogram dan pengembang perangkat lunak untuk mencari dan mengurangi bug, atau kerusakan di dalam sebuah program komputer atau perangkat keras sehingga perangkat tersebut bekerja sesuai dengan harapan. Debugging cenderung lebih rumit ketika beberapa subsistem lainnya terikat dengan ketat dengannya, mengingat sebuah perubahan di satu sisi, mungkin dapat menyebabkan munculnya bug lain di dalam subsistem lainnya, disampaikan oleh David J. Agans (2019 : 1) [4].

\section{Windows}

Sistem operasi Windows telah berevolusi dari MS-DOS, sebuah sistem operasi yang berbasis modus teks dan command-line. Windows versi pertama, Windows Graphic Environment 1.0 pertama kali diperkenalkan pada $\underline{10}$ November 1983 , tetapi baru keluar pasar pada bulan November tahun 1985, yang dibuat untuk memenuhi kebutuhan komputer dengan tampilan bergambar. 
Windows 1.0 merupakan perangkat lunak 16-bit tambahan (bukan merupakan sistem operasi) yang berjalan di atas MS-DOS (dan beberapa varian dari MS-DOS), sehingga ia tidak akan dapat berjalan tanpa adanya sistem operasi DOS dari informasi menurut Gary B Shelly (2018: 7) [5].

\section{Kamus Data}

Merupakan katalog fakta tentang data dan kebutuhankebutuhan informasi dari suatu sistem informasi atau kumpulan data mengenai data-data. Kamus data dibuat berdasarkan arus data yang ada di Diagram Alir Data. Kamus data dibuat pada tahap analisis sistem dan digunakan baik pada tahap analisis maupun pada tahap perancangan sistem. Pada tahap analisis sistem, kamus data digunakan sebagai alat komunikasi antar analisis sistem dengan pemakai tentang data yang mengalir di sistem. Sedangkan pada tahap perancangan kamus data digunakan untuk merancang input, merancang laporanlaporan dan merancang basis data.Rome Narayan ( 2012 : 11) $[6]$.

\section{Pengujian Perangkat lunak}

Software Testing atau Pengujian perangkat lunak merupakan suatu proses investigasi yang dilakukan untuk mendapatkan informasi mengenai kualitas dari suatu produk atau layanan yang sedang diuji, atau lebih spesifiknya software testing adalah proses mengeksekusi suatu program untuk menemukan bug (kesalahan atau cacat lainnya) dari perangkat lunak. Menurut Mauro Pezze (2019:9)[7].

\section{Perangkat Lunak Yang Digunakan}

Perangkat lunak (software) yang penulis gunakan dalam membuat aplikasi ini adalah sebagai berikut:

a. Dreamweaver cs3 adalah sebuah HTML editor profesional untuk mendesign web secara visual dan mengelolah situs atau halaman web. pada Dreamweaver cs3 ini terdapat beberapa kemampuan bukan hanya untuk mendesign web tapi juga untuk menyunting kode serta membuat aplikasi web dengan menggunakan berbagai bahasa pemrograman Web, antara lain : JPS, PHP, ASP dan ColdFusion [8]

b. Xampp adalah sebuah paket kumpulan software yang terdiri dari Apache, MySQL, PhpMyAdmin, PHP, Perl, Felezilla dan lain-lain. Xampp berfungsi untuk memudahkan instalasi lingkungan PHP, di mana biasanya lingkungan pembangunan web memerlukan PHP, Apache, MySQL dan PhpMyAdmin serta software yang terkait dengan pengembangan web[9].

\section{Metodologi Penelitian}

Metode penelitian rupakan suatu teknik atau cara untuk mengumpulkan data atau fakta yang nantinya akan dipelajari dan akhirnya sebagai bahan untuk di analisa serta digunakan untuk memudahkan pencarian dan pemecahan suatu masalah. Metode penelitian yang digunakan terbagi menjadi 2 yaitu metode pengumpulan data dan metode pengembangan perangkat lunak yang dapat dilihat dibawah ini:

\section{A. Metode Pengumpulan Data}

Metode pengumpulan data secara sederhana diartikan sebagai proses mengartikan data-data lapangan sesuai dengan tujuan, rancangan, dan sifat penelitian. Adapun teknik pengumpulan data dengan cara sebagai berikut:

\section{Observasi}

Yaitu mengamati secara langsung objek yang diteliti sehingga penulis memperoleh data yang akurat.

\section{Wawancara}

Yaitu tanya jawab langsung dengan orang-orang yang terkait dengan objek atau masalah yang sedang ditangani oleh penulis.

3. Studi Kepustakaan

Melakukan pengumpulan data secara tidak langsung dengan melakukan studi kepustakaan, yaitu dengan mengumpulkan data-data dan teori-teori yang berhubungan dengan penulisan laporan skripsi ini

\section{B. Metode Pengembangan Perangkat Lunak}

Metode pengembangan perangkat lunak yang digunakan dalam membangun sistem informasi ini menggunakan model Waterfall (Classic Life Cycle) yang menyarankan pengembangan perangkat lunak secara sistematik dan berurutan yang dimulai dari tingkatan sistem tertinggi dan berlanjut ketahap analisis, desain, pengkodean, pengujian dan pemeliharaan. Kelebihan dari metode ini adalah terstruktur, dinamis, dan sequential. Model Waterfall dapat di lihat pada gambar 1 .

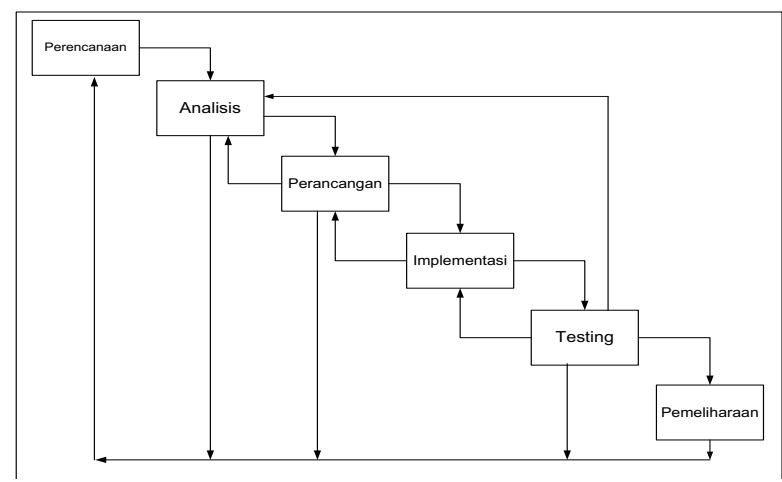

Gambar 1. Model Waterfall[10]

Paradigma dari tahapan model Waterfall adalah sebagai berikut:

1. Perencanaan, adalah apa yang dijelaskan pada bab ini yaitu menyangkut studi kebutuhan pengguna, studistudi layakan baik secara teknis maupun secara teknologi serta penjadwalan pengembangan suatu proyek sistem informasi dan atau perangkat lunak.

2. Analisa, yaitu tahap dimana kita berusaha mengenali segenap permasalahan yang muncul pada pengguna dengan mendekomposisi usecase diagram lebih 
lanjut, mengenali komponen-komponen sistem, obyek-obyek, hubungan antar obyek.

3. Perancangan, dimana kita mencoba mencari solusi permasalahan yang didapat dari tahap analisis. Tahap perancangan menekankan pada platform apa hasil dari tahap analisis kelak akan diimplementasikan.

4. Implementasi, dimana kita mengimplementasikan perancangan sistem ke situasi yang nyata. Disini kita mulai berurusan dengan pemilihan perangkat keras, penyusunan perangkat lunak aplikasi (coding).

5. Testing, apakah sistem yang kita buat sudah sesuai dengan kebutuhan pengguna atau belum. Jika belum, proses selanjutnya adalah iteratif, yaitu kembali ke tahap-tahap sebelumnya.

6. Pemeliharaan, dimana kita mulai melakukan pengoperasian sistem dan jika di perlukan melakukan perbaikan-perbaikan.

\section{HASIL DAN PEMBAHASAN}

\section{A. Perancangan Sistem}

Perancangan sistem secara umum bertujuan untuk memberikan gambaran secara umum kepada pemakai sistem yang baru dan juga merupakan persiapan dan rancangan terperinci dengan mengidentifikasi komponen-komponen sistem informasi. Rancangan ini meliputi Flowmap yang diusulkan, Diagram Konteks, Data Flow Diagram, Entity Relationship Diagram, Struktur Program

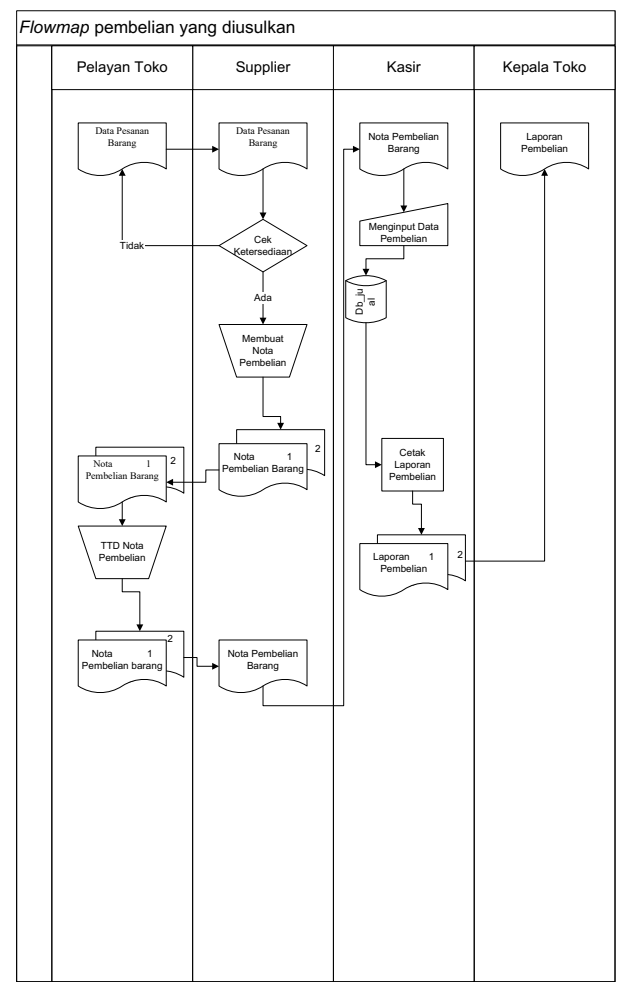

Gambar 2. Flowmap usulan pembelia

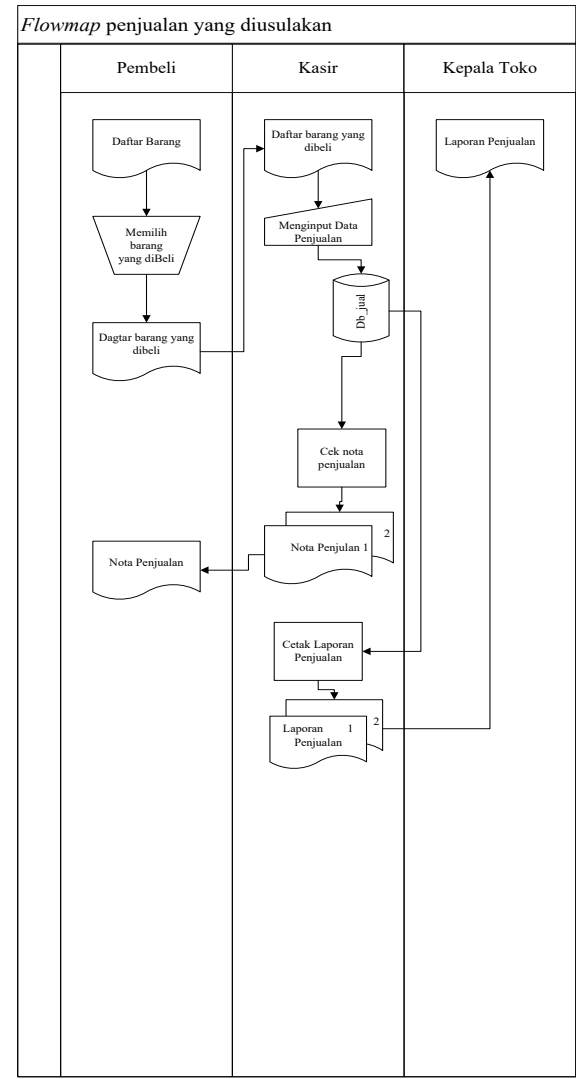

Gambar 3. Flowmap usulan penjualan

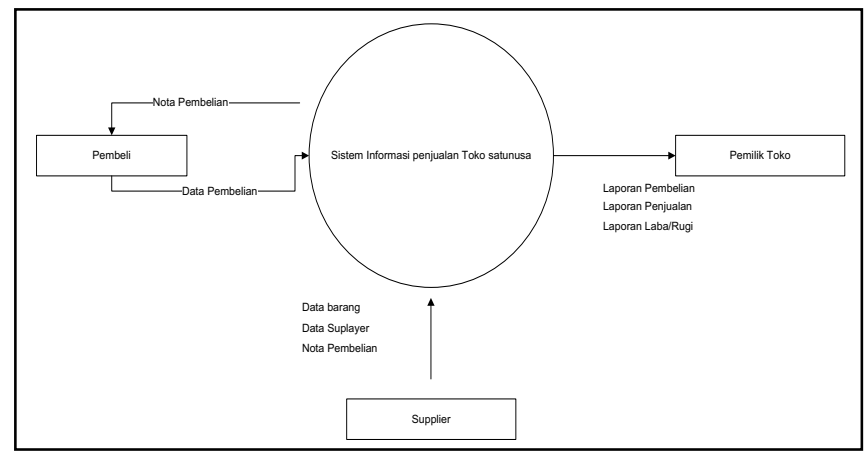

Gambar 4. Diagram Konteks 


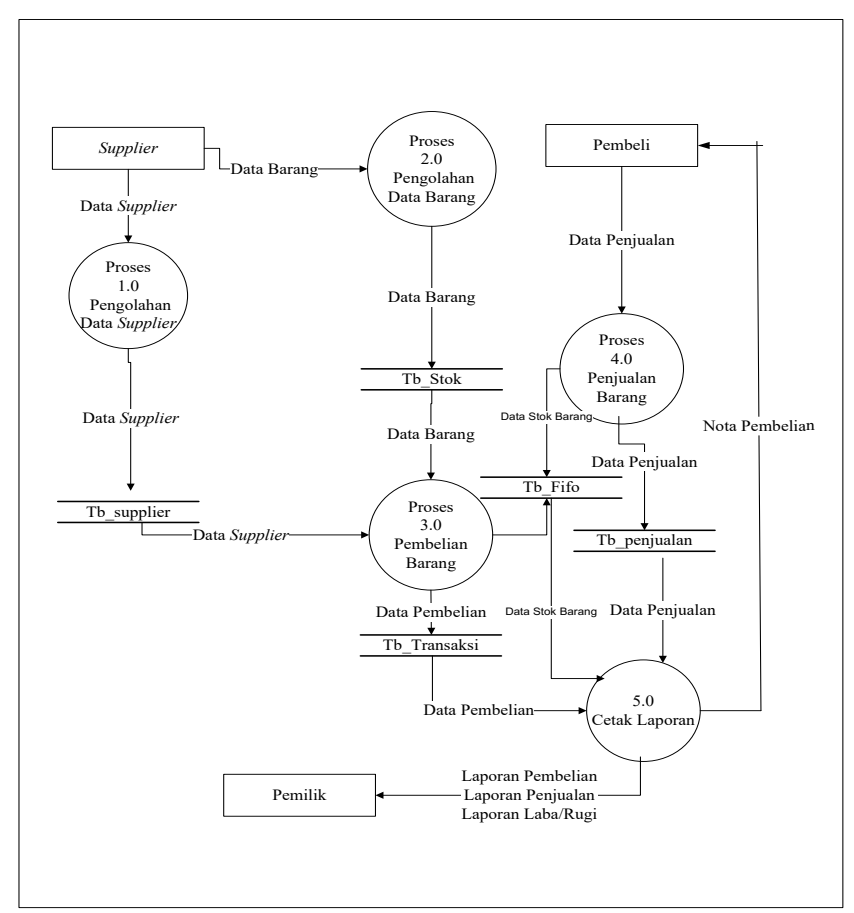

Gambar 5. Data Flow Diagram level 0

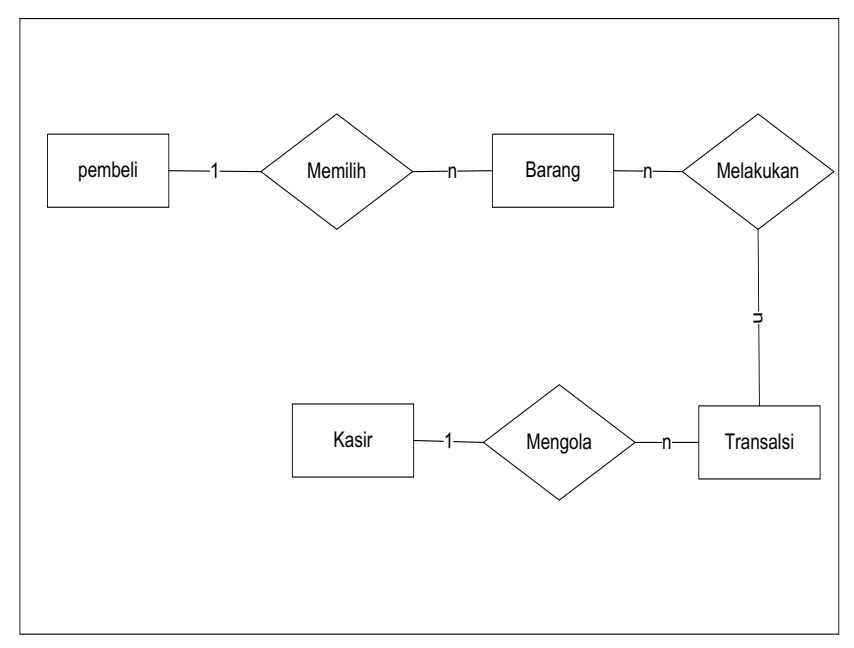

Gambar 7. Entity Relationship Diagram

B. Perancangan Struktur File

Dalam pembuatan aplikasi ini dibutuhkan suatu spesifikasi file untuk mempermudah dalam melakukan kegiatan pemrograman, yang dapat dilihat dari tabel - tabel berikut:

TABEL I

BARANG

\begin{tabular}{clcc}
\hline No & Nama kolom & Tipe data & Ukuran \\
\hline 1 & Barang_id & Int & 15 \\
2 & Barang_nama & Varchar & 150 \\
3 & barang_satuan & Double & \\
4 & barang_harpok & Double & \\
5 & barang_harjul & Double &
\end{tabular}

\begin{tabular}{clcc}
6 & barang_harjul_grosir & Double & \\
7 & barang_stok & Int & 11 \\
8 & barang_min_stok & Int & 11 \\
9 & barang_tgl_input & Timestamp & \\
10 & barang_tgl_last_update & datetime & \\
11 & barang_kategori_id & int & 11 \\
12 & barang_user_id & int & 11 \\
\hline
\end{tabular}

TABEL II

SUPPLER

\begin{tabular}{clcc}
\hline No & Nama kolom & Tipe data & Ukuran \\
\hline 1 & suplier_id & Int & 11 \\
2 & suplier_nama & Varchar & 35 \\
3 & suplier_alamat & Varchar & 60 \\
4 & suplier_notelp & Varchar & 20 \\
\hline
\end{tabular}

TABEL III

JUAL

\begin{tabular}{clcc}
\hline No & Nama kolom & Tipe data & Ukuran \\
\hline 1 & jual_nofak & Varchar & 20 \\
2 & jual_tanggal & Timestamp & \\
3 & jual_total & double & \\
4 & jual_jml_uang & Double & \\
5 & jual_kembalian & Double & \\
6 & jual_user_id & double & \\
7 & jual_keterangan & Int & 11 \\
\hline
\end{tabular}

TABEL IV

USER

\begin{tabular}{clcc}
\hline No & Nama kolom & Tipe data & Ukuran \\
\hline 1 & user_id & Int & 11 \\
2 & user_nama & varchar & 35 \\
3 & user_username & Varchar & 30 \\
4 & user_password & Varchar & 35 \\
5 & user_level & varchar & 2 \\
6 & user_status & varchar & 2 \\
\hline
\end{tabular}

TABEL V

KATEGORI

\begin{tabular}{clcc}
\hline No & Nama kolom & Tipe data & Ukuran \\
\hline 1 & Kategori_id & Int & 11 \\
24 & Kategori_nama & Varchar & 35 \\
\hline
\end{tabular}

C. Perancangan Struktur Menu

Struktur menu merupakan bentuk umum dalam suatu perancangan aplikasi yang dapat memudahkan pengguna dalam menggunakan aplikasi yang di bangun. Adapun struktur 
menu yang akan di implementasikan dalam apikasi ini adalah seperti gambar di bawah ini:

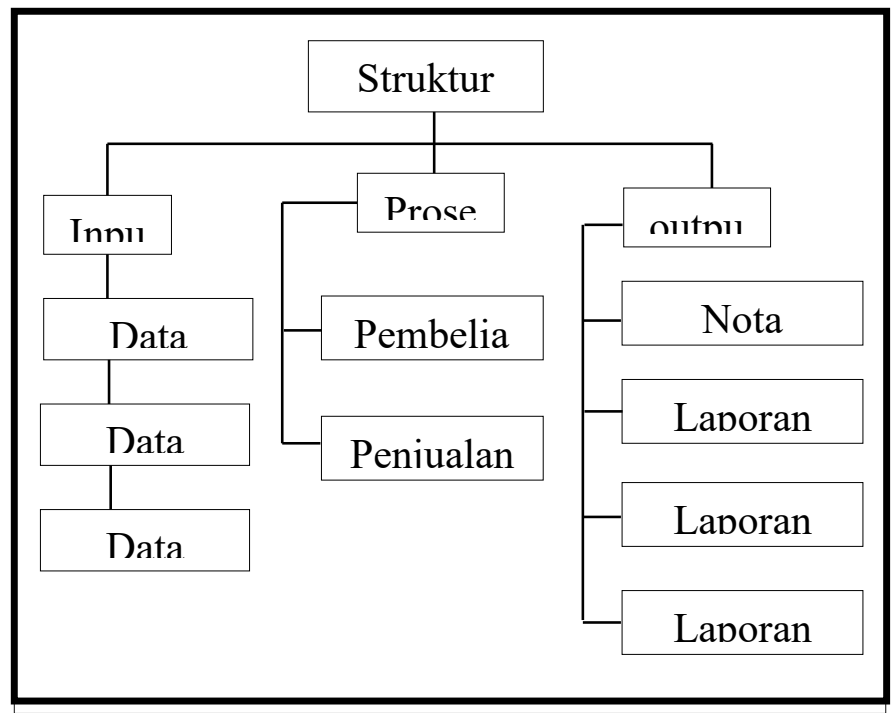

Gambar 8. Struktur Program

\section{Implementasi}

Sistem setelah dianalisis dan dirancang, maka sistem tersebut siap diterapkan atau diimplementasikan. Tahap implementasi adalah tahap dimana sistem informasi telah digunakan oleh pengguna. Sebelum benar-benar bisa digunakan dengan baik oleh pengguna, sistem harus melalui tahap pengujian terlebih dahulu untuk menjamin tidak ada kendala fatal yang muncul pada saat pengguna memanfaatkan sistemnya. Jika sistem perangkat lunak telah selesai melewati tahap pengujian sistem maka sistem perangkat lunak tersebut telah siap untuk digunakan. Penggunaan sistem perangkat lunak yang baru pada suatu organisasi atau perusahaan kadang- kadang merupakan proses yang tidak mudah sehingga persiapan untuk tahap ini harus dibuat dengan matang. Tampilan antar muka dapat dilihat pada gambargambar sebagai berikut:antar muka masukan data ke dalam database atau output dari database.

Gambar 9 adalah tampilan halaman login yang digunakan ketika admin pertama kali menggunakan aplikasi.

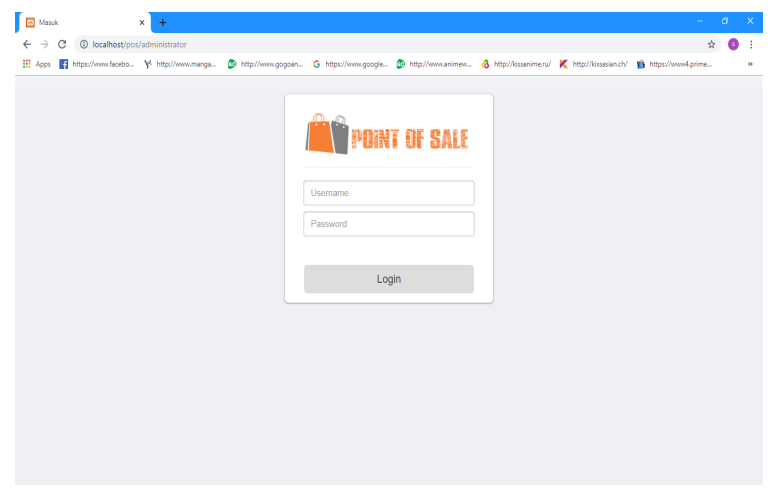

Gambar 9. Halaman Login
Gambar 10 adalah tampilan halaman utama digunakan admin untuk menginput dan mengelola data kebutuhan sekolah pada aplikasi ini.

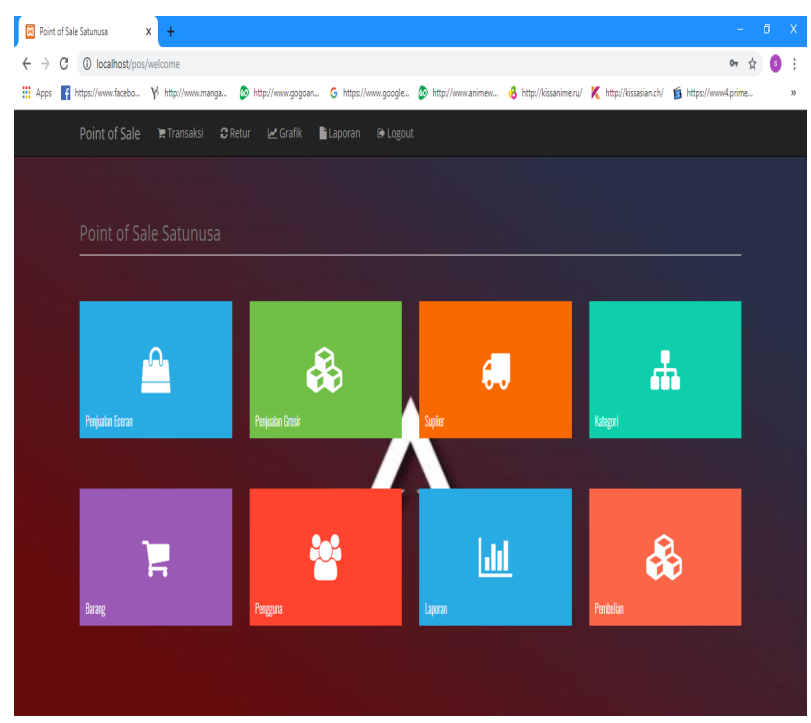

Gambar 10. Halaman Utama

Gambar 11 adalah tampilan form input data kategori

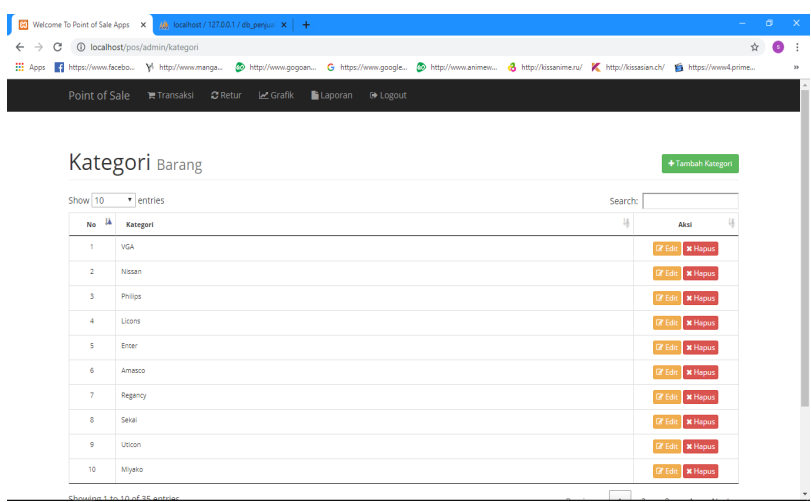

Gambar 11. Form input data kategori

Gambar 12 adalah tampilan form input data barang.

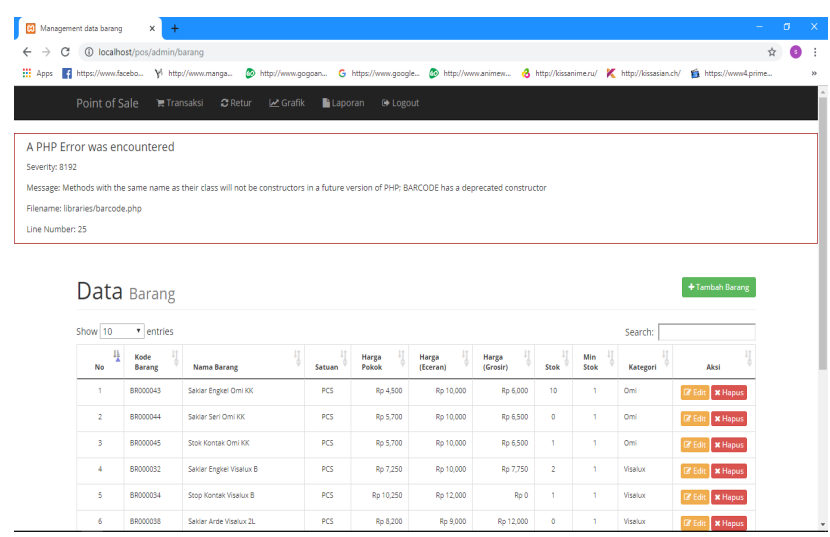

Gambar 12. Form input data barang

Gambar 13 adalah tampilan form input data pembelian. 


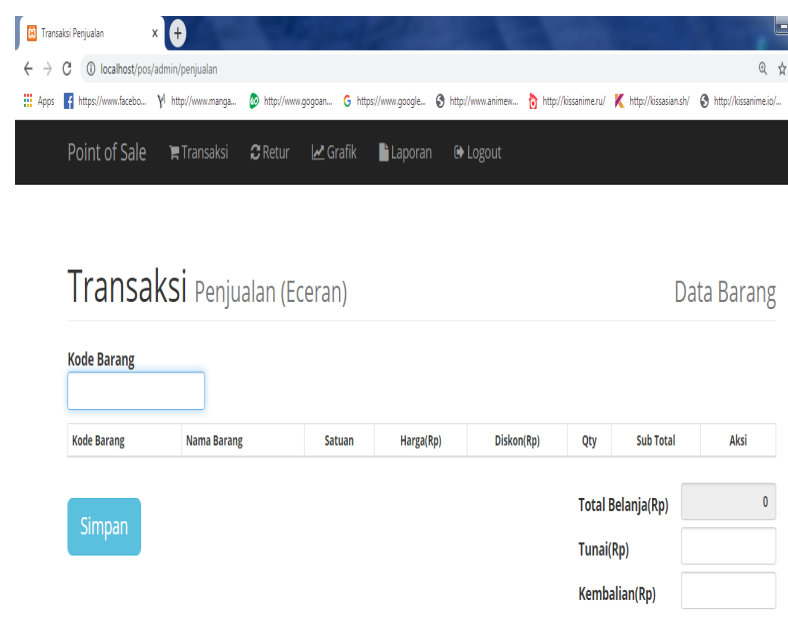

Gambar 13. Form input data pembelian.

Gambar 14 adalah tampilan form Laporan.

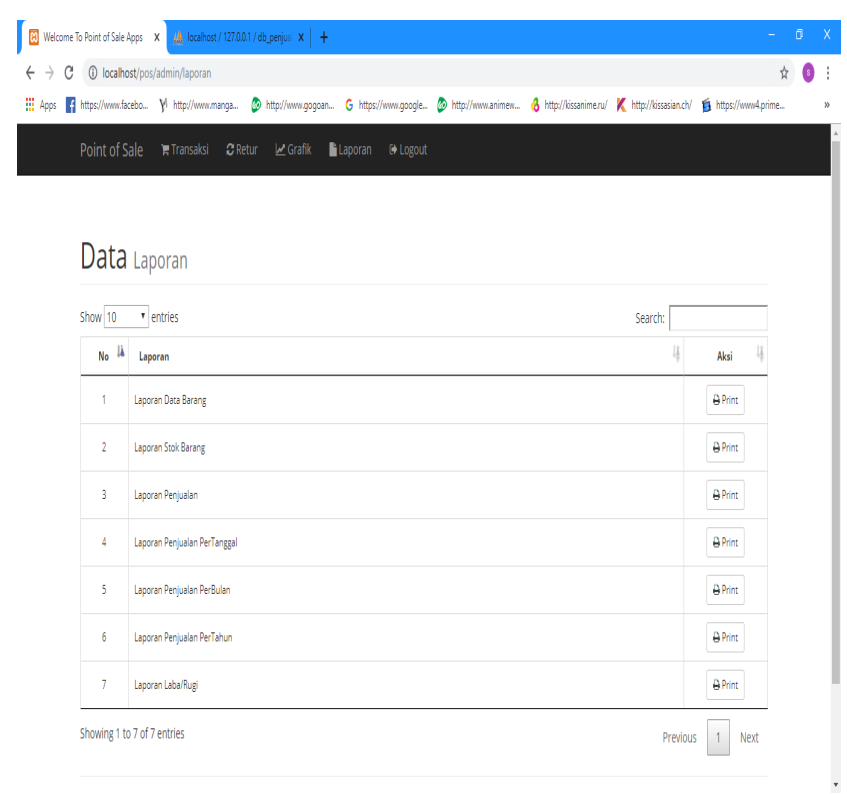

Gambar 14 Form laporan

Gambar 17 adalah tampilan halaman output data barang.

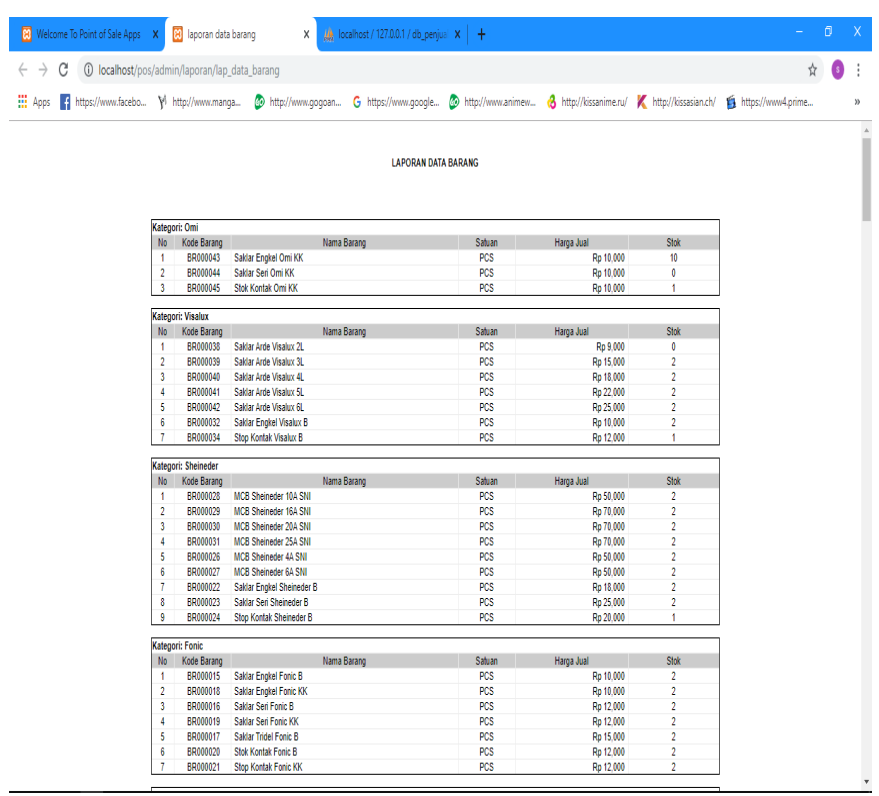

Gambar 17. Halaman output laporan data barang

Gambar 18 adalah tampilan halaman Laporan Stok.

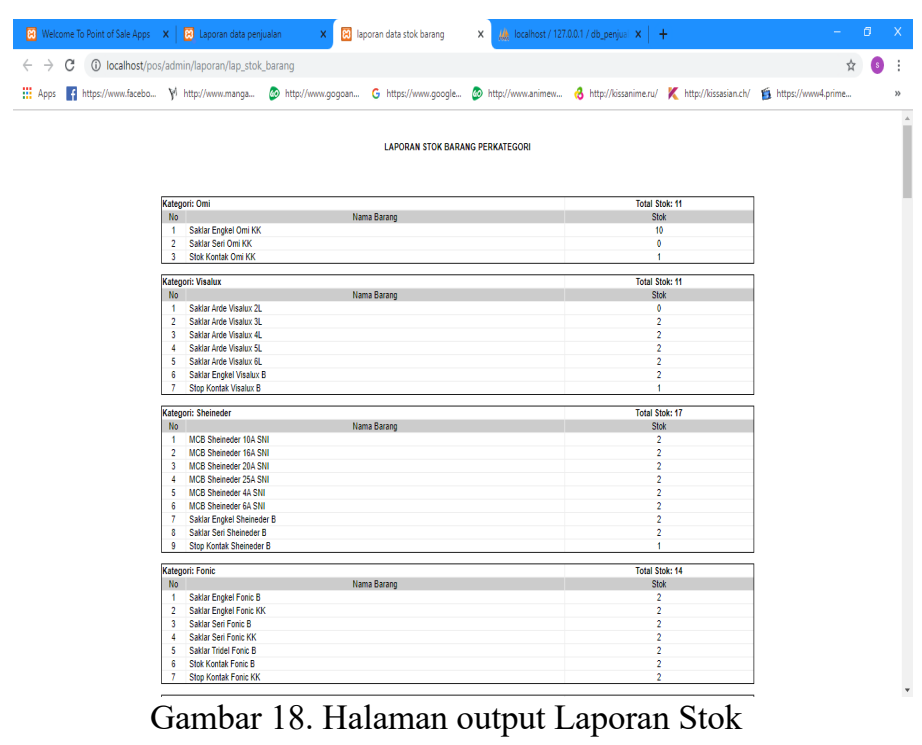

Gambar 19 adalah tampilan halaman output laporn laba/rugi. 


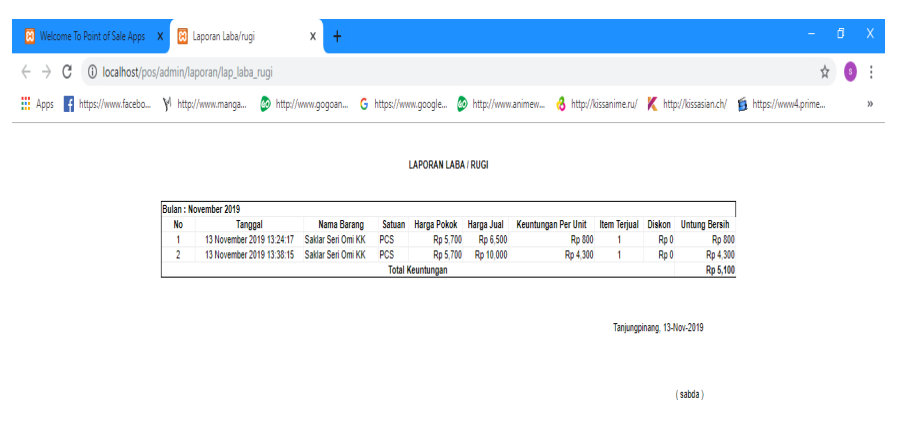

Gambar 19. Halaman output laporan laba/rugi

Gambar 20 adalah tampilan halaman output Laporan pejualan barang.

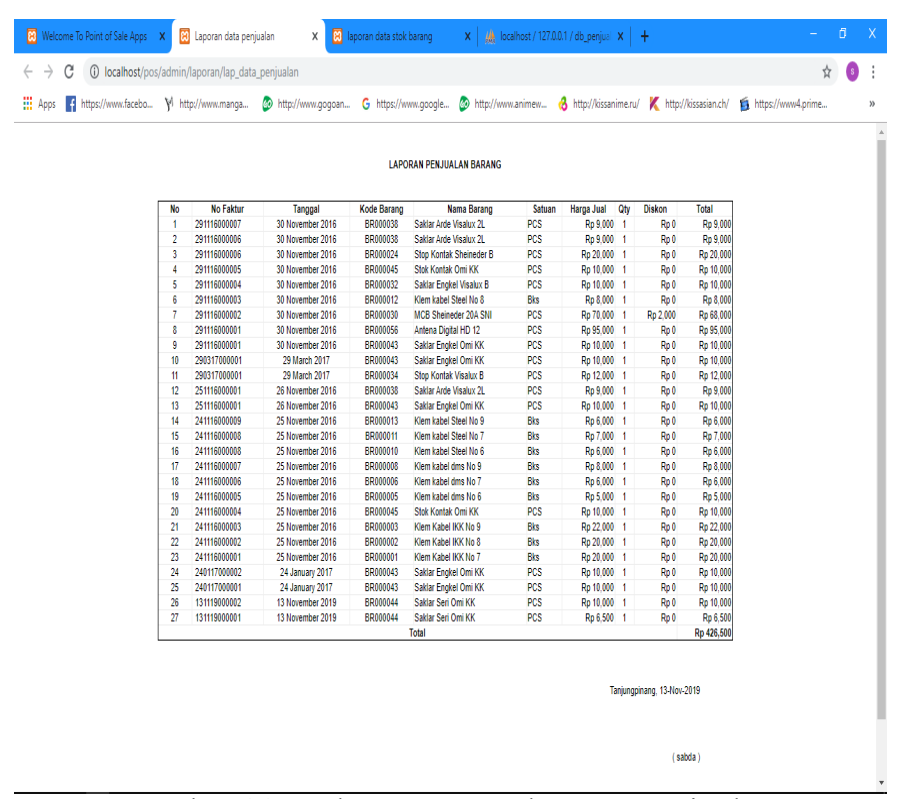

Gambar 20. Halaman output laporan penjualan

\section{KESIMPULAN}

Berdasarkan hasil implementasi Sistem Informasi Penjualan peralatan komputer diToko Satunusa Menggunakan website yang dapat disimpulakan sebagai berikut :

1. Dengan dibangunnya system informasi penjualan ini, yang pada awalnya system yang digunakan masih melakukan pengarsipan dalam penyimpanan datanya. Dengan sistem informasi yang di usulkan ini, proses penjualan produk dilakukan dengan berbasis web telah terkomputerisasi.
2. Dengan diterapkannya sistem ini diharapkan dapat mempermudah kinerja administrator ataupun pemilik dalam proses pengolahan data karena sudah mempunyai database yang terintegrasi, hal ini sangat efektif dan efisien bagi kinerja administrator.

3. Sesuai dengan Indentifikasi masalah yang di hadapi oleh user dalam melakukan proses barang yang masuk dan keluar.

\section{UCAPAN TERIMA KASIH}

Didalam pengerjaan laporan skripsi ini, penulis telah melibatkan banyak pihak yang sangat membantu dalam banyak hal. Oleh sebab itu, disini penulis sampaikan rasa terima kasih sedalam-dalamnya kepada :

1. Ibu Liza Safitri, S.T.,M.Kom., Selaku dosen pembimbing dalam penyusunan laporan skripsi ini.

2. Dosen - dosen Sekolah Tinggi Teknologi Indonesia Tanjungpinang.

3. Kepala Toko yang telah memberikan izin bagi penulis untuk mengadakan penelitian.

4. Orang tua tercinta yang telah banyak memberikan doa dan dukungan kepada penulis secara moril maupun materil hingga laporan skripsi ini dapat selesai.

5. Semua pihak yang telah banyak membantu penulis selama penyusunan laporan skripsi ini yang tidak dapat penulis sebutkan satu persatu.

\section{REFERENSI}

[1] Krismaji, Sistem Informasi Akutansi, 2015,

[2] Mardi, Sistem Informasi, 2014,

[3] Lewison M Dalen, Retailing, 1982,

[4] Agans J David, Debugging, 2019, New York.

[5] Shelly B Gary, Microsoft Windows 7, 2018, United States.

[6] Narayan Rome, Data Dictionary ,2012, New Jersey.

[7] Pezze mauro, Softwere testing and analysis, 2019,

[8] Zaki Ali, 36 jam belajar komputer dreamweaver cs3, 2018,

[9] Hidayat Heri, Cara Menguwasai Program websie ,2013,

[10] Pressman Roger, Rekayasa perangkat lunak pendekatan Praktisi , 2013, Yogyakarta. 